\title{
Antimicrobial Activity of Thymus vulgaris L. Essential Oil Against Coalho Cheese-Related Pathogenic and Technological Bacteria
}

Rayssa Julliane de Carvalho (I), Geany Targino de Souza (I), Neyrijane Targino de Souza (I), Danilo Elias Xavier (I), Maria Lúcia da Conceição (I), Marciane Magnani (I), Evandro Leite de Souza (I)

(I) UFPB - Federal University of Paraíba (Cidade Universitária, s/n - 58051-900 - Castelo Branco, João Pessoa - PB, Brazil)

\section{Resumo}

The use of lactic ferments or acid lactic bacteria (LAB) starter cultures provides milk protein coagulation by lactose fermentation and acid lactic production during the coalho cheese preparation. LAB action can also have an impact on organoleptic properties of the final product. These LAB cultures are often composed by Lactococcus lactis subsp. lactis and Lactococcus lactis subsp. cremoris. Coalho cheese is a satisfactory substrate for the growth of $\mathrm{LAB}$, and is considered a frequent vehicle for foodborne pathogens, including Staphylococcus aureus and Listeria monocytogenes. Plant secondary metabolism compounds have shown antimicrobial activity and have been frequently used by industry as food preservatives. The aim of this study was to evaluate the antimicrobial activity of the Thymus vulgaris L. essential oil (TVOE) against a lactic culture, composed of L. lactis subsp. lactis and L. lactis subsp. cremoris (Chr. Hansen ${ }^{\circledR}$ Brazil), commonly used as a starter culture in the coalho cheese production, and as well as against a mixed inoculum composed of $\mathrm{S}$. aureus ATCC 6538 and L. monocytogenes ATCC 7644. The TVOE was obtained from Ferquima ${ }^{\circledR}$ Ltda, and tested at concentrations of 0.3 to 40 $\mu \mathrm{L} / \mathrm{mL}$. The antimicrobial activity of the TVOE was evaluated by determining the minimum inhibitory concentration (MIC) using the microdilution in broth technique as recommended by the Clinical and

\footnotetext{
Referência:

Rayssa Julliane de Carvalho, Geany Targino de Souza, Neyrijane Targino de Souza, Danilo Elias Xavier, Maria Lúcia da Conceição, Marciane Magnani, Evandro Leite de Souza. Antimicrobial Activity of Thymus vulgaris L. Essential Oil Against Coalho Cheese-Related Pathogenic and Technological Bacteria. In: Anais do 12 Congresso Latinoamericano de Microbiologia e Higiene de Alimentos - MICROAL 2014 [= Blucher Food Science Proceedings, num.1, vol.1]. São Paulo: Editora Blucher, 2014. DOI 10.5151/foodsci-microal-333
} 
Laboratory Standards Institute (CLSI) and the resauzurina $(0.01 \%)$ as indicator of bacterial growth. The mixed inoculum of pathogenic strains (proportion of 1:1) and a culture of LAB strains was adjusted to containing approximately $10^{8} \mathrm{CFU} / \mathrm{mL}$. The TVOE showed a MIC value of 1.25 $\mu \mathrm{L} / \mathrm{mL}$ against the technological culture composed of lactic acid bacteria, and $2.5 \mu \mathrm{L} / \mathrm{mL}$ against the mixed inoculum of pathogenic strains. This result suggested that the use of TVOE as antimicrobial could be an alternative tool to inhibit pathogenic bacteria often found in coalho cheese. However, the fact that the MIC of TVOE against these pathogenic bacteria can also inhibit the LAB growth should be considered, once these LAB can provide a benefic effect on technological and sensorial characteristics of fermented dairy products.

Palavras-Chave: essential oil, antimicrobial activity, lactic acid bacteria, coalho cheese

\section{Agência de Fomento:}

